Portland State University

PDXScholar

\title{
Marketing in Portland's Small Publishing Industry: Case Studies in the Biographical Approach
}

Kate Jay

Portland State University

Follow this and additional works at: https://pdxscholar.library.pdx.edu/honorstheses

Part of the Entrepreneurial and Small Business Operations Commons, Marketing Commons, and the Publishing Commons

Let us know how access to this document benefits you.

\section{Recommended Citation}

Jay, Kate, "Marketing in Portland's Small Publishing Industry: Case Studies in the Biographical Approach" (2018). University Honors Theses. Paper 559.

https://doi.org/10.15760/honors.566

This Thesis is brought to you for free and open access. It has been accepted for inclusion in University Honors Theses by an authorized administrator of PDXScholar. Please contact us if we can make this document more accessible: pdxscholar@pdx.edu. 
Marketing in Portland's Small Publishing Industry: Case Studies in the Biographical Approach

By

Kate Jay

An undergraduate honors thesis submitted in fulfillment of the

Requirements for the degree of

Bachelor of Arts

In

English

And

Marketing

Thesis Advisor

Rachel Noorda

Portland State University

2018 


\begin{abstract}
This thesis seeks to understand the influence of a publisher's individual experience and background on the marketing functions of a small publishing press. In order to complete this task, the biographical approach was used. This approach requires interviews of small business owners in order to gain an understanding of their motivation, history, and background. Three Portland publishers of similar size but varying genre focuses were interviewed. The interviews were analyzed and treated as individual case studies. The results of the interviews and analysis was an understanding that the impact on a press from the owners' knowledge, personalities, and backgrounds change the structure of the individual press so wholly that from one publisher to another nearly an entirely new service is being provided despite the same product being produced-books. The thesis describes the importance of the qualitative knowledge and expertise of small business owners, specifically small publishers in the Portland publishing market. Using the biographical approach revealed that some of the key components of marketing within a small press are the relationships within the publishing community, the impact of distribution, and the overall desire to make a quality book for readers and create a quality experience for the author.

Introduction

Publishing can very simply be defined as the business of books. After a book's initial creation by the author, a publisher acquires it, edits, revises, edits again, designs a cover, distributes it, and finally, makes it marketable. These tasks require language expertise, design skills, and an ability to work with and understand people. The work of a publisher is not minute and it takes years to learn the basic skills required and requires constant adaptation to change. In large publishing houses, which make up most of the market share in book publishing, these tasks are handled in separate departments by people who are experts in their specific fields (Clark and Phillips, 2014). The covers are designed by graphic designers, the marketing accomplished by marketing managers, and each step of the process is segmented into small pieces, streamlined to the creation of a product and expedited to make as many books in a quarter as possible. In small publishing, however, all these tasks are completed by either a few individuals, or often, one alone. It is here my thesis seeks to understand who these individuals are and why, as well as how, they accomplish the marketing tasks that allow their presses to function.
\end{abstract}


This thesis looks at the small publishing industry in Portland from the perspective of the publisher. It seeks to understand the knowledge and history the publisher brings to a publishing house and how that history and knowledge influences the way they market books and market their press. Through conversations and interviews with three different Portland publishers who have vastly different approaches to the same basic tasks, this thesis contains three small case studies that don't seek to explain small publishing as a whole, but rather seek to understand these three individuals. From a small office above Union Station, to a basement physics lab to the PSU Writing Center, this thesis takes a unique look at the individuals that make up the small publishing industry and the knowledge they bring to their press that is unique, worthwhile to understand, and overall highly valuable to appreciating the individuals who incapsulate what small publishing is.

\section{Literature Review: Entrepreneurial Marketing}

The American Marketing Association defines marketing as “...the activity, set of institutions, and processes for creating, communicating, delivering, and exchanging offerings that have value for customers, clients, partners, and society at large" (American Marketing Association). Within every business and industry, the techniques utilized to accomplish marketing look vastly different, and explicitly or implicitly marketing activities are being accomplished; otherwise a business would be unable to function. However, many businesses, especially small businesses, are far less strategic in their marketing (Wing and Harker, 2015). Because of this it is beneficial to study and understand the business techniques taking place in small businesses in order to pinpoint the skills that are dismissed as unimportant because they aren't the same techniques and skills employed for marketing by large organizations. 
Marketing in small businesses is entirely different than what is expected in large firms, and the creativity of the individuals in charge becomes a major asset in continuing this crucial business function because the financial resources available to small business owners is nowhere near the capacity of larger firms (Jones and Rowley, 2011). Creativity can be found in businesses of any size, but it is the norm for small businesses. A small business can be defined as a business with fewer than 10 employees (Organization for Economic Co-operation and Development). In the last two decades, marketing in small business has been studied in far greater than ever before as there is a renewed acknowledgement that marketing in small business occurs, despite having a less strategic approach then medium and large businesses. The marketing within small businesses can be called "entrepreneurial marketing”. One journal article classified entrepreneurial marketing as “...a result of various factors including: small size; business and marketing limitations; the influence of the entrepreneur; and, the lack of formal organizational structures or formal systems of communication with sometimes no systems at all when it comes to marketing” (Jones and Rowley, 2011). Marketing in small businesses requires an understanding of the small business and the relationship it has to its market and the business stakeholders, and despite an informal approach, many small business owners inherently recognize and utilize this information (Morrish, Sussie, 2011).

\section{Literature Review: Qualitative Research in Marketing}

Creativity and adaptability shape modern marketing and the study of marketing itself has changed. This period in the history of academic marketing research can be referred to as the "Discovery Period", as this is a time in the marketing field in which the idea of marketing in a solely scientific and quantitative sense is no longer widely accepted by the business community because it no longer fits the identity of marketing practices. Rather, there is a need to consider 
marketing both a science and an art in order to grasp the wide variety of tasks that must take place in order for marketing to function best (Shaw, 2011).

Ian Fillis, a marketing researcher from the University of Stirling in Scotland, has spent the last 25 years studying marketing within the realm of small businesses, particularly those of the creative industry. Fillis states that those working with marketing as a small business "...must acquire and practice creative entrepreneurial marketing in order to successfully differentiate their businesses in the increasingly competitive cultural industries marketplace" (Fillis, 2004; Shaw, 2011). The "cultural industries" can be defined by "activities which deal primarily in symbolic goods -goods whose primary economic value is derived from their cultural value"; some examples include film, publishing, design, architecture, visual art, crafts, theatre, concerts, and museums (O'Connor, 2011).

Thus, Fillis championed a research approach to marketing within small businesses and the cultural industries referred to as the "biographical approach." The biographical approach works best for small companies in which one or a few individuals participate in the majority of "big picture" decisions being made. The approach acknowledges that the work being completed by small business owners, as well as their education, interests, and personalities, is valuable in understanding the business' success. Furthermore, it suggests that the creative and intuitive decisions made by the business owner is more valuable to them as an asset in marketing than using additional (and often unattainable) financial and labor resources. In essence the methodology of this approach explores the benefits of utilizing methods outside traditional business research in order to further understanding of entrepreneurial marketing that exists outside the confines of what we traditionally see as marketing behavior (Fillis, 2005). 
Ian Fillis' approach has been adopted a number of times for various studies as a tool to understand small business activities that fall outside the realm of what traditional business research studies. Examples include Stephanie Duchek's study, "Entrepreneurial resilience: a biographical analysis of successful entrepreneurs" which looks into what in the background of an entrepreneur leads to a resiliency for change and the desire to persevere in business. This research was completed through interviews with eight successful entrepreneurs to learn about their personal histories (Ducheck, 2017). Similarly Roger Bennett's study "How small charities formulate marketing responses to major reduction in income" which sought to understand how individual business owners of small performing arts centers will change tactics with a loss of governmental funding and whether this was impacted by personal belief by interviewing 26 small, nonprofit contemporary dance companies (Bennett, 2014). Both these researchers interviewed multiple owners/managers of businesses across the industry they studied, as is suggested in the outline of the approach. Completing the interviews with multiple businesses allows for cross examinations of the interviews and seeks to find patterns that may fall across an industry. This then introduces an element to the study in which the approach can add to the research of an industry at large, rather than as a case study of a singular business. Because, however, the results focus on the individual, the research can't be generalized across every small business within the industry, which is one of the values of the approach; it values the impacts made by individuals.

Another important aspect of the biographical approach is the need for analysis from a qualitative perspective. The interviews seek to understand what the creativity of an entrepreneur brings to their business' marketing, yet how can creativity be categorized? This question can be answered through tools utilized by more qualitative and ethnographic research, including 
thematic coding. Thematic coding, a tool commonly used throughout ethnographic research allows the researcher to categorize information collected from interviews and look critically for commonalities or key phrases that are necessary for understanding the business functions (Davis, 2014). Thematic coding creates a structure in which the responses from open-ended questions can be categorized and synthesized, so the most valuable information in an interview to a research question can be analyzed (Vaughn and Turner, 2015).

Finally, the use of the biographical research necessitates the use of other research as well as it cannot wholly capture a business without building off industry research that currently exists. In conjunction with other research on an industry, the biographical approach deepens the understanding of a business and the owner that cannot be captured by traditional research methods (Fillis, 2005). Within the context of this thesis, the biographical approach was the method in which the case studies were completed and through the addition of deeper knowledge on marketing and the publishing industry as a whole; it is research situated within the context of larger research on the publishing as it exists today in the 21st century.

\section{Literature Review: The Publishing Industry}

The work of this thesis revolves around the publishing industry, particularly small house publishing. In order to situate the completed research in existing work, a deeper understanding of the publishing industry, specifically marketing, must occur.

It is no surprise the publishing industry has gone through vast changes in the last two decades since the digital revolution. Yet what is potentially surprising is exactly what these changes are. Because of the shrinking market as entertainment options grow outside of traditional media, large publishing houses consolidated in order to retain their market share and this has had a major impact on the publishing industry at large (Thompson, 2010). The five 
biggest publishers, commonly referred to as the "Big 5", Penguin-Random House, Macmillan, HarperCollins, Hachette, and Simon \& Schuster, have an oligopoly on the industry. These publishers continue buying more small publishers and have an overwhelming buying power in the marketplace, which means they also have control over the distribution chain and the greatest power among booksellers (Squires, 2007). There are also concerns with the consolidation process that fall outside the realm of business functions, much of which are founded in the social impact of books as a form of media. Books have faced censorship for the entirety of their existence, and the fear of large media corporations owning book publishers adds to the fear of censorship from within, rather than from an outside entity. A simple example of this occurred in 1998 when Rupert Murdoch, CEO of News Corp owners the publisher Harpercollins shut down the publishing of a novel for fear it would impact business in South Korea (Squires, 2007). As these fears continue to prosper, especially since the 2013 combination of Penguin and Random House, the two largest publishers, small publishers find themselves fulfilling important niche markets as they are more willing to publish books based on content, rather than profitability (Thompson, 2010).

Culturally, the consolidation of the publishing industry may be beneficial to small publishing houses as they are able to maintain a level of transparency the Big 5 houses cannot (Thompson, 2010). Financially however, small publishing houses face a great deal of challenges because they simply cannot compete with the large houses marketing budgets, labor resources, and available distribution channels.

The question of whether or not the publishing industry will survive in the digital age has been a concern since the invention of the computer. However, sales of print books have risen every year since 2013 and in 2017, print book sales were up 10.8\% compared to 2013, a surprise 
to many and a positive outlook for the publishing industry (Milliot, 2018). However, the impact of ebooks is one of note, especially to the small publishing industry. Because of the cost of publishing in terms of print and distribution, ebooks allow small publishers to produce books far more cheaply, but this doesn't necessarily mean it's easier for publishers to get these books to an audience (Esposito, 2011). Over the last two years, there has been a decline in e-book sales, while the sale of print books remained steady and even increased (ibisworld). In 2017 alone, ebook sales fell 10\%, and 16\% the year prior (Milliot, 2018). Another interesting change within recent years of publishing has been growth in the audio book market. In 2016, the sales were up $18.2 \%$ from the year previously and was even higher, up over 20\% for 2017 (Anderson, 2017). The changing market of publishing means publishers, large and small, must pay attention to trends in order to stay relevant and reach an audience who will be interested in their titles in the format of their choosing.

There are several challenges facing publishers in their efforts to remain financially viable and reach their intended audience. Two of these unique challenges for publishing include distribution and returns. Distribution in the publishing industry can be a massive challenge for small publishers. A 2017 article referred to it as the "hardest piece of the publishing puzzle" and it's clear to see why (Sullivan, 2017). Distributors require a great deal from publishers before they are willing to distribute their books. An example is Consortium Book Sales \& Distribution who requires a publisher to publish eight books a year prior to even considering their bid to distribute for them (Consortium Book Sales \& Distribution). For small publishers, who often publish between one and five titles a year, distribution assistance from distributors like Consortium are out of the question. Finding a distributor who will take a risk on a small press is 
highly challenging, and without distribution, getting books into the hands of readers is far more challenging.

Similarly challenging, is getting books onto the shelves of bookstores. As Amazon prospers, small bookstores across the country falter and struggle to stay financially afloat, meaning they must save limited shelf space for books that can be guaranteed as a sale, which frequently means books from small publishers are overlooked as they don't have the large marketing backing that larger publishers can offer (Squires, 2007).

Another unique characteristic of the publishing industry is the existence of returns. During the Great Depression, people were far less inclined to spend on books, therefore stores were far less inclined to take a chance on buying books for their shelves they may never sell. To combat this fear and get books onto the shelves of bookstores, publishers began offering returns (Thompson, 2010). When a bookseller buys books from a publisher, a bookstore can return the books to the publisher at no cost to them. This practice has remained since its development in the 1930s and benefits booksellers greatly, but puts publishers at risk for all sales, as they cannot be guaranteed to make a profit until the book is in the hands of readers. When books are returned to publishers, often publishers find it more financially viable to pulp the books rather than pay for additional storage space for the books (Squires, 2007).

Despite the changing market and the small market share, and the difficulties in distribution and returns, there are small publishers across the world that are functional, adept, and flourishing. In Oregon there are over 70 small press and literary magazines listed with Portland's Literary Arts, a nonprofit dedicated to the Oregon literary community, and there are likely many more who were not listed with the organization (Literary Arts). Small publishing houses often situate themselves within a niche market which is a key to their success. These 
markets include very specific genres, specific authors, and publishing in communities in which the publishers' networks exist (Bold, 2016).

Though there is a strain on small publishing houses, they continue onward and progress through a process of trial and error and still manage to successfully generate enough money to stay afloat and publish more books. It is here where my research comes into play as I seek to discover how the individual owners of publishing houses are doing this.

\section{Methodology}

To fulfill the objectives of the research, the method utilized to complete the research was the biographical approach, the approach utilized in a marketing and small business context by Ian Fillis In order to use the biographical approach with a focus on the publishing industry, several factors were taken into account. The approach requires interviewing small business owners in order to understand what they do, their personal history, and their business (and personal) goals.

One of the first considerations in finding publishing houses to interview for this project was who to interview and why. Portland State University is home to Ooligan Press. Ooligan Press is one of the only completely student-run trade presses in the United States (Ooligan). Because of this, Portland State has a connection to many Portland publishing houses, which was highly beneficial in terms of locating publishing houses and publishers to contact. Furthermore, Portland has been a hot spot for small publishing. Due to Portland's positive relationship with small businesses, local connections, and a large literary community, the small publishing industry has found a haven in the city (Bold, 2011). These factors, as well as ease of reaching individual publishers to perform the interviews made Portland the ideal location to begin research. 
From this point, a list was gathered of local publishers who could be contacted. Literary Arts has a list of small publishers and literary magazines, which was beneficial, but one of the most beneficial sources of contact was Melanie Bold's journal article “"Accidental Profession'” Small Press Publishing in the Pacific Northwest.” In this article, Bold interviews small publishers from throughout the Pacific Northwest including publishers from Washington, Oregon, and Idaho. Serval publishers in the study were from Portland and they were asked to participate in the research. Another source of gathering contact, was the advisor to this research, Dr. Rachel Noorda, who had several contacts from her work with Ooligan Press. A total of ten publishers were contacted, of which three responded with agreements to participate. These three publishers were Jay Nadeau of Biting Duck Press, Dan DeWeese of Propeller Publishing, and Michael Heald of Perfect Day Publishing. Three publishers were enough for this project due to the scope, the length of time available to complete the research, and the available resources. Furthmore, because the goal of the research was to study the individual businesses and their owners as case studies, it was not necessary for the sample to be representative of the Portland publishing industry as a whole. All interviews and research occurred after approval was received from the International Review Board (See Appendix B for interviewee consent form).

The interviews occurred on three separate days in the locations of the interviewees' choosing. Each was given a consent form to have their information published through the written thesis. The individuals were interviewed for information about their business, their individual personalities, and their various skills. The interview questions are purposely personal, as the biographical approach suggests that the individuals who run a business are successful because of the skills and passion they personally bring to a business. The approach is designed to validate the skills of the small publisher in that even if they aren't from a business background, they bring 
a specific knowledge to their business that is unique to them and allows their business to function.

The questions for the interviews were adopted from Fillis' article "The Biographical Approach to Researching Entrepreneurship in the Smaller Firm" (Fillis, 2002). Within this article, Fillis describes the value of each question in how it highlights specific valuable information from the interviewee that provides a full picture of the individual's history, and their business motivations (See Appendix A for Interview Questions). Some questions were changed and added in order to fit the publishing industry. For instance, questions about relationships with authors were added, as well as questions about why the interviewees were interested in the publishing industry itself.

In order to study the interviews appropriately, thematic coding was used to analyze the data. Thematic coding of interviews is a tool to study qualitative data thoroughly and from an analytical lens. Thematic coding is used in case study research for interviews, ethnographies, and more (Davies, 2014). In order to code interviews thematically, interviews are transcribed and answers from interviewees are scanned for relevant key words that return throughout the interview or are highly important when they are mentioned. The thematic codes for this research were specified after all three interviews took place and feature themes that were discussed frequently by one, two, or all of the interviewees. Because the goal of the research isn't to define the Portland publishing industry, information that only arose in one of the interviews was still valuable, as each interview was a short case study on the individual publisher and publishing house. The information sought was about the marketing aspect of their business needs and how the personal beliefs, passions, and skills of the publisher impact the way they market their 
business, and the products and books they sell (For a list of the chosen themes for analysis, see Appendix D).

The themes incapsulate much of the information pulled from the interviews, and they allow for thorough analysis of both individual beliefs and skills of the publisher, while at the same time provide information on the business aspect of their publishing house. It is from these themes that the following analysis of each of the interviews takes place. For contingency and flow, the individual thematic codes are not labeled in the analysis, rather the data retrieved from the thematic coding was synthesized and used to shape the following analysis.

\section{Michael Heald- Perfect Day Publishing}

In a small office on the third floor of Union Station there are approximately 50 rent controlled offices. It is here that Perfect Day publishing exists. Perfect Day publishing is a creative nonfiction press that publishes one book a year and has been doing so since 2011 . Michael Heald is the owner, founder, and publisher for Perfect Day Press. Perfect Day has published six authors and a total of seven books with another title coming out in the Fall of 2018. Each book costs $\$ 10.00$ or less to purchase and has been the case since the press began. There are no full-time employees of Perfect Day Press and Michael Heald does not make a profit from the press.

Michael Heald comes from a literary background in that he himself is an author. Along with running the press, Heald works as a freelancer writer for magazines including Runner's World Magazine (Perfectdaybooks.com). In his twenties, Heald wrote his first novel and sought to get it published. After sending his manuscript to many publishers with no success, he made the decision to stop writing for two years. When he began writing again, he was drawn into the publishing world and started his publishing house with the help of the Independent Publishers 
Resource Center and so Perfect Day began (Nicholson, 2017). Because he was unable to publish his own first novel, Heald took the opportunity of owning an independent press to ensure fewer individuals will feel the frustration and disappointment he felt when he began. For this reason, Heald works with authors who have never been publisher and whom Heald believes have the chance to succeed once they get are given the chance to get their work out into the world.

The importance for Heald of assisting an author in creating a worthwhile book and helping them break into the industry can be clearly seen in the interactions he has with his author's and the way he discusses supporting them and their endeavors. The relationship between publisher and author carries a great deal of weight for Heald and is a place from which Heald gains a great deal of passion from the press. Perfect Day has had six authors over the last nine years and with each one, Heald valued the relationship with the individual author he published. One of the books published by Perfect Day was written by Heald himself, but the others were written by authors Heald found. Perfect Day Press does not take submissions or manuscripts regularly. This is a fairly common practice for publishers of all sizes because the reading manuscripts requires a great deal of time. Because of this though, it means Heald must discover the authors he works with himself. Some of these authors were friends of his, while others he sought openly. For instance, one author who has been published by Perfect Day twice, was an individual who Heald messaged over Facebook because he was impressed by her other work. Heald works one on one on a constant basis with these authors while the book is being edited, designed, and marketed. Several times throughout the interview Heald repeated phrases like "I owe it to the writers" and made statements about how publishing a writer's book can change their life. 
Large presses are unable to supply this meaningful connection between an author and a publisher. For one, there are so many different departments in the large publishing house, there isn't a single person to refer back to. Another major impact is how many books these editors and publishers are working on in a major house. These houses are publishing multiple books a week, if not multiple books a day and there isn't the time nor the need to focus heavily on making a single author feel at ease and cared for unless the press knows their author is one who will be a major financial asset to the press. Perfect Day, on the other hand, works with an individual author for over two years from acquisition to marketing after the book is published. As a marketing tool, this attracts authors and books Heald will feel passionate about and gives authors an individualized experience and this experience is part a huge part of the service a publisher supplies. Publishers are not selling only books, they are providing a concrete and powerful service to an author.

The conversation about relationships leads directly to the passion Heald feels for publishing. In the interview, two questions specifically asking about passion and interests in publishing were asked. However, through the conversation and answers provided by Heald in other questions, passion for various aspects of publishing and the business can be implied.

When asked what his favorite part of Perfect Day was, Heald mentioned his joy watching authors have realizations about their work and getting to see an author's work come together. Heald also eloquently described why the work of Perfect Day is valuable to society at large. Heald stated "I also know that writing has always mattered, like capturing a person's complicated interiority is always a valuable thing to be doing" (Heald, 2018).

The passion for individual books and for the author's work is what allows Perfect Day to continue to operate. It is not a quantifiable business function and yet it fulfills the American 
Market Association's definition as it creates value for "customers, clients, and partners". The author's experience is made much more valuable because Heald is willing to work with them constantly and help them along the way. This passion differentiates Heald from large publishers and Perfect Day gains a great deal from this both personally and professionally. He is able to do a job he enjoys and he feels is worthwhile, while at the same time his passion encourages authors to maintain a belief in their work, because he believes in their work.

Another valuable aspect of relationships mentioned by Heald were the connections and friendships he has made in the Portland publishing industry since 2011. Heald mentioned several times that he is not the designer of the covers, nor is he the singular copyeditor. He employs two individuals to do this work for him. These individuals, and the authors of the books, are the only individuals paid by the work of Perfect Day. Each time Heald discussed the copyeditor and designer he referred to them as friends. The friendship element of the press is a part of the press' brand, in that these relationships are part of the grassroots aspect of the press, adding to its local Portland feel. The "grassroots" feel of Perfect Day is both a necessity due to the size and available resources Perfect Day has as well as part of the appeal of working with Perfect Day publishing as an author or bookseller looking to encourage the small business aspect of the Portland publishing industry. The grassroots nature of Perfect Day defines what Michael Heald wants for his business. He doesn't want to publish more than a book a year, so he continues Perfect Day while at the same time maintaining his own writing and his other passions.

An example of this is how Heald described his press to ElevenPDX, a creative industry magazine in the Portland area supporting local businesses. Heald described his press as similar to an independent record label. Heald stated: 
I thought, if this thing is modeled after a record label..., I could work with people like Martha Grover (who is my favorite writer who hasn't hit it big yet) as an investment in our mutual futures together, kind of like how a band would (Nicholson, 2017).

In the interview for the research of this thesis, Heald stated he has many friends in the music scene in Portland. Heald wants to take a first-time author and propel them forward into other opportunities and he sees the press as a first step for authors he believes can go further and do more. When these authors then succeed, Perfect Day itself benefits in the long run. This approach encapsulates how Heald approaches marketing. With the idea that the long-term benefits of crafting a good product and a meaningful connection with an author will far outweigh the benefits of publishing a large number of books he spent less quality time with.

Another connection mentioned frequently throughout the interview was a connection to Dan DeWeese. Dan DeWeese is a publisher with another publisher house with whom Heald distributes with. These small presses work in tangent with one another and share a very similar approach. Heald mentioned on multiple occasion that he and DeWeese share similar viewpoints on the finances of their presses and the aesthetics of their books. Another publisher was mentioned as well, Future Tense Books, and Heald discussed the differences between Perfect Day and Future Tense. It's interesting to note the while we were talking about small presses that were similar to Perfect Day, the discussion of them wasn't a discussion on competition, rather community. These presses have partnerships and a relationship of friendship rather than a competitive one. The other presses are seen as assets to Perfect Day and the community Heald has developed over his nine years as a Portland publisher is an impressive one. One of the biggest impacts on the publishing industry is highly limited shelf space and despite this, competition from other small presses is not of major or mentioned concern. Perfect Day is a 
community affair because Heald finds a great deal of enjoyment and fulfillment from running a press that operates with the assistance and input of others.

Heald brings skills to Perfect Day that he has acquired over the years from experience within publishing and from being a writer himself. When asked what his skills were, Heald mentioned that he is good at motivating people. From his experience with the seven authors he has worked with over the years (six previous and the current author), Heald knows how to keep the authors engaged and working on their manuscript by working with them closely. Helping authors remain confident in their work while receiving constant feedback is not an easy task and Heald accomplishes it well. His background as an author himself allows for him to understand the pressure an author is under. He can work with them directly and meet the where their at in the creative process because he has been through it and can help these first-time authors through it too.

Heald also mentioned skills in project management. Again, over the years Heald has worked with many books. With the work comes experience in understanding the schedule of a book. Unprompted, Heald several times listed the points in the year in which he knows when we will be busy and when he can rest more easily. This is highly valuable knowledge because it keeps a project moving when it otherwise would potentially fall stagnant. The ability to manage a schedule relates directly to marketing. A marketing necessity is knowing where to perform a task as well as when. Heald described in detail the timing of his book's production and the timing of a book's promotion. Heald works in the Portland community because he knows the people and he knows he can get people to show up for promotional events. Heald ingrained himself in the Portland culture and Perfect Day benefits. Experience takes time to build and the 
nine years in which Heald has been involved with publishing is an asset that builds over time and cannot be developed overnight.

Though Heald does a great deal for the marketing of his press and the books he writes, there are certainly marketing tasks Heald chooses not to perform. When asked what skills Heald believes he is lacking, he mentioned social media. Perfect Day does not have a social media presence, nor do most of the individual books. This is a rarity within publishing because a social media presence helps with brand development, and gets people interested and aware of the work being completed by a press (Criswell, Jamie and Canty, Nick, 2014). This may however lead to branding, intentional or not, for Perfect Day. There is a market for individuals who are opposed to mainstream marketing techniques and not using social media, for an intended purpose or simply for lack of it in Perfect Day's case, means it could help reach people who are opposed to social media. The issue with this being: how then do you reach people who don't want to be marketed to? Perfect Day finds itself facing this dilemma, which is related to Heald himself, who doesn't want to perform typical marketing techniques to market his books and press.

It is important to note the money is not the reason Heald runs Perfect Day. Financially speaking, publishing is not a lucrative business. Many publishers, including Heald, work to make enough money to support the next book they wish to publish. All of Perfect Day's books sell for $\$ 10.00$ or less, which is not a typical way to price books as a product. Heald began this practice with his first book and has continued it to this point. This price point covers the books costs, the author's royalties and assists with the next book's production, but it doesn't provide any additional income for Heald and Heald does not expect it to any time in the near future. In addition to running the press, Heald works as a bartender and writes his own work as a freelancer and author. 
Not gaining financially is not an uncommon occurrence for small publishers and it means many small publishers gain in intangible and other tangible ways from their business. For Heald this gain is in the creation of books that Heald believes in. Putting new literature into the world and supporting individual authors who hold similar values to him provides him with enough satisfaction and worth to keep the press going and keep the press alive.

Despite gaining value from the press in other capacities besides financial, Heald still hopes to one day make money from the press. Mentioned several times throughout the interview, Heald considers what would happen if one of the published pieces makes it big. Though Heald repeated doubt of a major success multiple times, it did continue to come up as an aspiration for the press and in his thoughts for the future of the press. It's interesting to note how Heald mentioned these vague aspirations before shutting them down, as it seemed he believed they were unrealistic aspirations. As this impacts marketing, Heald takes this potential goal and completes the tasks that often feel like a waste of time, yet they open the door to the potential success Heald talks of. Heald sends review copies to Publishers Weekly, The New York Times, and other big reviewers because receiving a big review from these organizations could shape the sales of a book drastically. Despite knowing the chances of this happening are slim to none, Heald still applies himself to marketing in this capacity and it is a strong point of his marketing. He takes his hope for the future and his care for the author's work and dedicates himself to the marketing despite his distaste for it, because he knows it must be done for the book to have a chance in the world.

Heald knows small publishing from the inside out. As a writer himself he takes his knowledge, as well as the knowledge he's gained over the years and a publisher and makes a book the best it can be. From there, he sells it, distributes it, and does his best to help the book 
and the author make a mark on the literary world. Marketing does not always look like a social media presence, advertisements, and massive events. For Perfect Day Press, marketing is relationships: relationships with publishers, with authors, and with the Portland literary community at large.

\section{Dan DeWeese- Propeller Publishing}

Before Propeller Press came to be, there was Propeller magazine. Started in 2009, the literary magazine features articles on the current happenings of the literary world, works of fiction and poetry, and Question and Answer segments with authors local and beyond. Editor and Chief of Propeller magazine, Dan DeWeese decided a publishing press would be perfect accompaniment for the magazine and so Propeller Books was born. Propeller books publishes one piece of literary fiction a year, and have done so since 2010, except for one year where no book was published. The sole publisher, editor, designer (interior and exterior), and founder of Propeller Press is Dan DeWeese.

The interview with Dan Deweese took place in the Portland State Writing Center, which DeWeese runs. He is also a senior writing instructor at Portland State and a published author with two books and a number of published short fiction pieces. With all these additional job titles, DeWeese has no need to make money from Propeller Press and financial gain is not the reason for DeWeese's interest in book publishing. This short case study seeks to understand why Dan Deweese began the press, why he continues, and what he brings to the press in skills and knowledge that keep the press afloat.

Deweese got into publishing because of his experiences with Big 5 Publishing. In 2011, a year after Propeller Press was created. DeWeese published a novel You Don't Love This Man, with HarperCollins. In the interview DeWeese talked about that experience and views it quite 
negatively. While he is content with his work, he felt his publishing experience with HarperCollins was impersonal and cheapened by the lack of personal interactions. Furthermore, he was given no say into the cover and internal design of his book which ended up with a cover DeWeese felt disconnected from and unhappy with. The Big Five publishing experience DeWeese described is the opposite of the experience Propeller Press provides its authors.

DeWeese himself admitted this influenced the way he runs Propeller and it is clear to see. As mentioned, DeWeese does everything for the press from designing to editing to acquisition and the aesthetics of the final product in look, feel, and quality matter greatly to DeWeese. Having one individual complete the entirety of the process gives his press a cohesiveness he didn't receive while working with HarperCollins. DeWeese also invites the author to have a say in each of the steps in the process which again is a way for him to take a stance against the business approach of the Big 5 publishers.

When it came to discussing skills, DeWeese was vague in his responses. When asked what skills he had, he replied, somewhat jokingly "All of them". He isn't incorrect though. For Propeller Press, DeWeese does everything, which is not small feat, especially considering all his outside work as well. DeWeese gained the ability to do everything for his press through a great deal of work and time gaining appropriate experience. For instance, DeWeese learned about design through an undergraduate degree in film, which helps him with the tangible aesthetics of the book making process. Related to this even is the word "aesthetic". DeWeese utilized the work himself with a great deal of frequency which is why it was chosen to use when discussing his press and abilities. The look and feel of a book, and the need for it to match the interior content is highly important to DeWeese likely because he understands the value on a deeper level because of his work studying and analyzing film, which he continues to do at PSU as an 
instructor of Portland State's "Writing about Film" class and other film-literature combined courses. DeWeese also has a vast knowledge of the story making process. As a writing instructor he helps students in their path to writing to the best extent of their abilities and he facilitates the Portland State University Writing Center as well: a campus resource designed to aid students not just in the editing process, but in the writing process as a whole. DeWeese can apply all this background knowledge in his day jobs and education to his work at Propeller press. Without this background, Propeller would not be as successful as it is. Interestingly, when asked if there are any qualifications necessary to be in publishing, DeWeese said no. While there are no specific qualifications, no need for a background in business, and no need for a specific degree, there are certainly a vast number of skills you must have in order to perform the tasks of a publisher, from time management to the ability to copy edit.

In terms of distribution, DeWeese mentioned it's the press' biggest challenge and his least favorite part of the job. Bookstores are inundated with the number of new titles coming out each year. What used to be new titles in the thousands is now new titles in the millions and shelf space is slim and getting slimmer as booksellers often make less on book sales than they do in gift merchandise. This means booksellers are forced, for financial reasons, to push books they know have a backing and a following, which are books that have marketing resources behind them, which often means books published by the Big 5 publishers. DeWeese talked about this at length because one of the biggest struggles for Propeller is getting books on the shelves, of no fault of booksellers nor of DeWeese himself. This is a major struggle for the press. DeWeese stated he has the knowledge of marketing to sell books, but the press lacks the resources. There is no budget for a full-time marketer and there isn't going to be one in the near future. Which means getting books into bookstores will continue to be a challenge for Propeller. 
Marketing is not a cheap activity and the publishing market is fraught with its individual challenges. Still though, Propeller books do sell for the simple reason they are beautifully created and well-written books. The most recent title The Horse Latitudes was an Oregon Book Award finalist. In terms of marketing, having a worthwhile product that caters to the target market is key to all other activities. It is this activity that DeWeese has succeeded at and continues will continue to bring Propeller success as times moves forward.

Another skill DeWeese mentioned was a necessity for running a press was creativity. He believes creativity is a necessity in publishing, but specifically for small publishing. When asked if he thought it was needed to be a publisher he was careful to make that distinction. Again, the influence of the HarperCollins experience he has was made apparent. Large publishing presses, while in the creative industry, view books as their commodity and product. DeWeese views his books as an art made for their stories and their aesthetic pleasure. The artistic focus DeWeese brings through his personality and background is highly influential in how he markets his books. Viewing books as an art, not a product means the book shouldn't be marketed in a mainstream capacity, and DeWeese adamantly chooses not to market his books like a product.

Throughout the entirety of our conversation, DeWeese was open about the finances of Propeller, in that the publishing press is not bringing in more money than what will be used for the next title. In fact, DeWeese seemed concerned that this may not be true forever and he was potentially reaching a point in which he may have to publish a book he is less passionate about, but will sell more. Despite this, DeWeese was clear that making money was not the goal of his process and his press. He is content with his other work financially and doesn't need to rely on Propeller for financial gain. 
From a marketing perspective, this is an interesting approach. His lack of desire for financial gain goes against the common curve of business as the definition of business is "the practice of making one's living by engaging in commerce" (Merriam Webster). However, DeWeese is still doing marketing, just with a different goal in mind. His goal is to get books and projects he cares about into the world and into the hands of others who will care about the projects. The goal isn't to have a huge best-seller that caters to a wide audience. Rather, it is to craft and sell inspiring, thought-provoking works than DeWeese personally believes should exist in the world.

DeWeese believes firmly in the art of the book. As an instructor of Rhetoric and Composition at Portland State University, DeWeese spends his daily life teaching others what encourages others to read, what persuades, and what appeals to the eye. From a background as a film major as an undergraduate and an MA in writing, DeWeese's passion for the aesthetics of a book make sense. This personal background and story shape the way he runs his press as an individual business owner. DeWeese believes firmly in creating art and through this creation of art and the crafting of a beautiful piece of fiction, in content and design, DeWeese markets his books to individuals he believes will appreciate it. DeWeese's focus on the aesthetics is a marketing technique of its own — Crafting a product that will appeal to its audience, an audience that is like him.

$\underline{\text { Jay Nadeau- Biting Duck }}$

The basement of the Portland State science building is filled with whirring equipment and running laboratories. It is in one of these tucked away labs that Jay Nadeau does most of her work as a physics professor and researcher at Portland State University, previously she was a professor of Biomedical Engineering at McGill University. The Nadeau Lab Group describes 
their laboratory as "An interdisciplinary laboratory in the Department of Physics, part of the Environmental Extremes Cluster. We do optical instrument development, software, nanomaterials, and basic microbiology" (Nadeau Lab Group). Nadeau, in her limited spare time, also runs Biting Duck Press.

Biting Duck came to be when Nadeau was on sabbatical in 2011 and found herself with extra time. With this time, she decided to build a literary press and named it Biting Duck after her livestream of her pet ducks she had set up in her backyard. The press publishes books about scientist fiction, not necessarily science fiction. The main genre Biting Duck seeks to work with is that of fictional scientists who do actual science. Since its creation in 2011, Biting Duck has published over 100 novels with the help of Nadeau, their volunteer staff, and freelancers they pay for things they personally cannot accomplish. In that time they also acquired another press, Boson Books. Nadeau is the only one of the three publishers interviewed who has open submissions on their website and the only publisher with more staff than the founder. Like the others, however, except for freelancers and authors, no one is paid from the work of the Biting Duck.

Nadeau does not come from a literary background in the slightest. The skills she developed as a scientist, however, help her a great deal with the press. First of all in terms of the books themselves. The goal of Biting Duck is to publish books with real science. There is no far reaching, inexplicable sci fi happening in the books published by Biting Duck. Rather, the books often center around fictional scientists who rely on real feasible science to propel their storylines. The reason the books can be based around real science is because Nadeau and Biting Duck's other volunteer editors are scientists. This fulfills an interesting niche market of other scientists 
and academics who are frustrated with fake science fiction that doesn't make sense and Nadeau gives these readers, who are much like herself, books that cater to them.

One of the most necessary skills for a publisher to have is the ability to read quickly and edit thoroughly. Despite note having an English background, Nadeau writes lengthy research papers ad nauseum. Nadeau mentioned the skills she developed in this area through her career and her education, writing dissertations and theses, aided her a great deal when she began publishing books.

A potentially less obvious, but still vastly important skill Nadeau brings to the press from her science background is an analytical approach to the business side of Biting Duck. In the interview, Nadeau described in detail situations involving distribution, formatting, eBook files and HTML without prompting. These are issues Nadeau chooses to pay attention to rather than hire a freelance designer most of time. One of the reasons for this is her ability to problem-solve. When asked if she enjoyed problem solving, Nadeau agreed promptly and replied "it's basically all I do". And that's true. Nadeau problem solves as a scientist and she problem solves as a publisher in a similar, analytical capacity.

The skills of a scientist are not expected assets to a press, and yet for Nadeau they aid her directly. One of the major assets of the biographical approach is to demonstrate the knowledge of business owners that doesn't directly fall into what is quantifiable in a quantitative research approach. The benefits of a scientific background for Nadeau and Biting Duck press are exactly the skills the biographical approach seeks to value and appreciate. Biting Duck press publishes many novels each year and as such, they have many authors who they work with. The majority of correspondence with these authors takes place electronically. 
Nadeau prefers it this way because, as she mentioned herself, the authors she works with are strange and often far away as they take open submissions from anywhere on their website.

Biting Duck has a goal to be highly cost effective and the most cost-effective way to publish books is electronically. However, authors prefer their books to be published in print and be in bookstores. Despite being less cost effective this way, especially when Biting Duck began in 2011 and eBooks were still selling at a high rate, Biting Duck began publishing books in print almost as soon as they started publishing. Catering to the author's wants and needs is a unique feature of many small presses, including Biting Duck. In particular cases they will cater to very specific requests including printing in hardcover if that's what the author wants. This is a fantastic draw for authors who are seeking to be published and is a great way for Biting Duck to continue to attract the authors they want to publish and who want to publish with them. As a marketing tool to make Biting Duck attractive to work with, it succeeds greatly.

In relation to other publishing houses and the publishing community at large, early on in the existence of Biting Duck Press, Nadeau stumbled upon Boson Books, a publishing house she was drawn to because of the physics based name. In quantum mechanics, a boson is a particle that follows Bose-Einstein statistics. Bosons make up one of the two classes of particles (Encyclopedia Britannica). When she reached out, they informed her they were selling their press and sold it to Nadeau for a highly discounted rate. In publishing, acquisitions are highly common. However, for a press as small as Biting Duck to purchase another is rare, much like the circumstances in which Biting Duck bought Boson. The purchasing of Boson Books relates to how niche this community is. Likely Boson Books was willing to sell so cheaply to Biting Duck because they sell similar titles and knew Biting Duck would be able and willing to support the authors Boson worked with. 
As a mostly digital press, one of the biggest challenges for Biting Duck is distribution. With authors across the country and in the UK and Canada, reaching bookstore shelves in those areas can be a wholly different beast. Nadeau problem solves much of this herself. In terms of finding affordable distribution channels, she is the force behind those operations. Biting Duck frequently struggles to get books into the world and into the hands of people who want them. Because of this, Nadeau plans to continue problem solving this aspect of the business until the books are in the world in the capacity she feels fit.

This passion and drive to get the books out into the world once again related back to Nadeau's own personality as an excited researcher seeking the answer to the problems she encounters and solving them one by one.

Nadeau's love of problem solving and desire for accurate science in novels has already been mentioned and fall into what Nadeau is passionate about. However, what hasn't been mentioned is how a scientist came into the literary world in the first place. When asked if Nadeau had always been interested in publishing she replied reading was one of her earliest passions, but she didn't know how to apply that passion to a career and so she instead went a more scientific route. Biting Duck is a fulfillment of both of her dreams: literature and science. Because she has no need or desire to make money from the press, she can simply do it for the joy of problem solving and the joys of bringing together literature and science.

Biting Duck press publishes many novels each year and as such, they have many authors who they work with. The majority of correspondence with these authors takes place electronically. Nadeau prefers it this way because, as she mentioned herself, the authors she works with are strange and often far away as they take open submissions from anywhere on their website. 
Biting Duck has a goal to be highly cost-effective and the most cost-effective way to publish books is electronically. However, authors prefer their books to be published in print and be in bookstores. Despite being less cost effective this way, especially when Biting Duck began in 2011 and eBooks were still selling at a high rate, Biting Duck began publishing books in print almost as soon as they started publishing. Catering to the author's wants and needs is a unique feature of many small presses, including Biting Duck. In particular cases they will cater to very specific requests including printing in hardcover if that's what the author wants. This is a fantastic draw for authors who are seeking to be published and is a great way for Biting Duck to continue to attract the authors they want to publish and who want to publish with them. As a marketing tool to make Biting Duck attractive to work with, it succeeds greatly.

Like the other two presses interviewed, Biting Duck's employees don't make money. Again, they don't necessarily intend to. The goal of Biting Duck is to publish the books the Biting Duck volunteers want to see in the world and help authors fulfill their dreams. Nadeau mentioned one of her favorite parts of Biting Duck was being able to publish authors who many have been rejected hundreds of times. Watching authors publish the work they care about, being able to support them and watch them grow is one of the greatest assets Biting Duck has.

For Jay Nadeau, a passion for problems and a love of literature drew her to the publishing industry, and to the publishing industry Nadeau brought her own unique skills—concrete and scientifically sound science fiction. Nadeau created Biting Duck to fulfill a niche only someone like her could fill, and through her technical and analytical methods, she tackles marketing in a step by step formulaic method that allows Biting Duck to function and get books into the hands of readers who want books that only a publisher like Nadeau could provide. 


\section{$\underline{\text { Discussion and findings }}$}

The interviews completed showcase the individual identities of the publishers of each press and the impact their personal stories and backgrounds have on the work they complete. From Jay's background as a scientist leading her to the joy of problem solving involved in owning a literary press to Dan's history and disillusionment with major literary presses and the way they work with individual works to Michael's passion for helping authors along their writing path. The value of the information provided seeks to demonstrate the power of the individual press owner, as none of the interviewees were the same as one another yet all were brought to the press with a purpose: to publish books they care about.

Though the numbers of interviews completed are not enough to make broad, generalizing statements about the publishing industry in Portland, there are commonalities and differences within the three interviews that are interesting to note.

An important characteristic none of the publisher's share are the anticipated futures for the press. DeWeese wants to keep publishing a book a year, when and if he chooses. He only wants to publish books he personally believes in and will hopefully bring in enough money to pay for a book the following year. Heald wants to continue with Perfect Day as planned, however he considers the possibility of a big break for his press, the hope one day a book will make it as a best seller more often than the other two publishers mentioned this hope. Nadeau focused on smaller goals, such as fixing the logistics of digital picture books and the formatting problems that come with e-reader formats. These differences demonstrate clearly that though publishing houses are inherently similar in product, they are vastly different in conception. Each of them desires a different experience and outcome from their press. The differences can be related back to their personalities and histories. Nadeau loves to problem solve and therefore her 
goal is to tackle each new problem as it comes along to the best of her ability. DeWeese wants to have authority alongside the author of the books he produces because of he knows from his experiences with Big 5 Publishing the implications and downsides of losing ownership of the work. Heald faced a disheartening experience early on with publishing and perhaps his internal desire, despite not expecting an outcome, for a big success comes from his early faltering attempts. A big success for Heald would mean a big success for the independent creative business process he believes in fully. Overall, the interviews provided insight into how the different biographies of the publishers shape their current press, and the future they imagine for their press.

Within the education and histories of the interviewees, there are some commonalities, particularly between Michael Heald and Dan Deweese. Not only do DeWeese and Heald know and work together personally, but both Heald and DeWeese are from a literary background. Both are published authors themselves and both have a similar approach to their press in that they are designed to publish one book a year, leading the authors through the experience in a hands-on manner. DeWeese and Heald also began their presses out of a disheartening experience with the publishing industry and a desire to change it. Nadeau on the other hand, prefers not to meet with her authors in person and talked about the authors at a greater emotional distance than the others. Nadeau also publishes more books each year and comes from an entirely different fieldphysics. The distinction between Propeller and Perfect Day compared to Biting Duck is vast and this is inherently caused by their personal backgrounds, as their personalities and knowledge change the goals of the press. Both Heald and DeWeese are far more focused on the forward motion of the author and the quality of the book in an artistic sense, Nadeau is focused more 
specifically on creating books that are creatively based around real science that exists in the world. She creates books for her target market, other scientists.

Within these differences though, an obvious shared commonality between all three individuals exists, the desire to publish books. Each publisher, for varying reasons, was drawn to the publishing industry to create books. Whether because they saw a lack of what they wanted in the world or because they wanted to help others make their art a reality. An affinity for literature shaped each of their lives. Interestingly though, each of them also maintains another job and doesn't financially benefit from the press. Lack of financial gain is highly common in small, independent presses and the lack of funding means the benefits of running a press come from an internal passion and desire rather than a financial need. From the interviews with Nadeau, DeWeese, and Heald, it's clear this remains true for them and they have a larger cultural desire for their business - they want to publish books that matter to them, to their audience, and to the world at large.

Another highly valuable similarity between all three publishers was their creativity. When asked, all three answered the question asking if creativity is a requirement to be in the small publishing industry with an adamant yes. The creativity involved not only in the literary and design aspects of publishing, but also the business side of publishing. With a small press comes a lack of financial stability, meaning all business activities must be done with as little money as possible and forces a creativity that large presses with monumental budgets do not have to face on a day to day basis. Working with complex schedules of maintaining another fulltime job along with the press also involves time management, self-motivation, and an immense amount of creative problem solving. Though the measurement of creativity has no concrete formula, many studies have been done on the various personalities traits that can be considered 
as creative traits and situations that lead to creativity (Fillis and McAuley, 2000). A full list of these qualities can be found in Appendix E, but some pertinent examples include: curiosity, independence, motivation, limited resources, innovation, and developing relationships. Throughout the interviews, each of the interviewees demonstrated several or all of these qualities in themselves and in their press. It takes a great deal of creativity to begin a literary press and even more to keep a small literary press afloat in the current market.

In terms of marketing, the skills the publishers bring vary greatly in what they want to do and what they seek for their press. Because these individuals run such small organizations, an overarching concept is that they themselves are their brand. It is clear in the strategies they seek to use, or not use. DeWeese mentioned catering his press' marketing to the brand of the press, Heald mentioned not using social media because he personally lacks interest in social media, and Nadeau mentioned working with distributors who will help her get books into stores. These all align with their individual identities. One of the benefits of owning a press and being your own company is the ability to do the activities you want to further the reach of your small business. This is highly beneficial in terms of branding because it creates a consistency readers and consumers will seek, because the brand is consistent with a single individual, not with a team attempting to create a brand image that fits the desires of an audience. To consider marketing relationally, rather than audience-seeking, these presses and allow their audience to find them because none of them would be willing to change what they love and craft for their press to suit what they believe the mass market would want and that is key to their marketing and brand personas. 


\section{Conclusion}

The research and subsequent thesis sought to explore the relationship between an individual press owner and the marketing of the press. Through individual case studies with three Portland publishers, Michael Heald, Dan DeWeese, and Jay Nadeau, the thesis described how individuals impact their business no matter their background and the background, interests, and personality they do bring to the press gives them a strategic competitive advantage in the world of publishing that attracts readers to their books and attracts authors to them. In an industry that has changed dramatically in the last two decades, small publishers stay afloat because of the skills, passion, and creativity they bring to their press. 


\section{Bibliography}

Anderson, Porter. "Audio Publishers Association: Third Year of Strong US Audiobook Sales Growth.”. Publishing Perspectives, 25 Jan. 2018.

Bennett, Roger."How small charities formulate marketing responses to major reductions in income: A study of nonprofit contemporary dance companies". Qualitative Market Research: An International Journal. 2014. Vol. 17 Issue: 1, pp.58-76.

Biting Duck Press. bitingduckpress.com. Accessed February 2018.

Bold, Melanie. "An "Accidental Profession": Small Press Publishing in the Pacific Northwest" Publishing Research Quarterly. 2016, pp. 84-102.

Brown, Stephen. Consuming Books: The Marketing and Consumption of Literature. Print. 2006.

Criswell, Jamie. \& Canty, Nick. Deconstructing Social Media: An Analysis of Twitter and Facebook Use in the Publishing Industry. Publishing Research Quarterly. 2014. 352-375.

Clark, Giles and Phillips, Angus. Inside Book Publishing. Print. 2014.

Davies, Martin. Doing a Successful Research Project: Using Qualitative or Quantitative Methods. $2^{\text {nd }}$ Edition. 2014.

"Definition of Marketing." AMA, American Marketing Association.

DeWeese, Dan. “Interview with Dan DeWeese- Propeller Press.” 15 Feb. 2018.

Duchek, Stephanie. "Entrepreneurial resilience: a biographical analysis of successful entrepreneurs". International Entrepreneurship and Management Journal. 2017. 2018, Volume 14, Issue 2, pp 429-455.

"Entrepreneurship - Enterprises by Business Size - OECD Data." TheOECD, Organisation for Economic Co-Operation and Development.

Esposito, J.J. One World Publishing, Brought to You by the Internet. Publishing Research Quarterly. 2011, 13-18.

Fillis, Ian. "A biographical approach to researching entrepreneurship in the small firm". Management Decision. 2006, pp. 196-212.

Fillis, Ian and McAuley, Andrew. "Modeling and Measuring Creativity at the Interface". The Marketing and Entrepreneurship Interface. 2000. Vol 8, pp 8-17. 
Fillis, Ian and Rentschler, Ruth. "Using creativity to achieve an entrepreneurial future for arts marketing". International Journal of nonprofit and Voluntary Sector Marketing. 2005. Vol 10, Issue 4.

Forest Avenue Press. Accessed October $30^{\text {th }} 2017$

Hawthorne Books. Accessed October $30^{\text {th }} 2017$

Heald, Michael. "Interview with Michael Heald- Perfect Day.” 14 Feb. 2018.

Hollier, Nathan. "Australian Small and Independent Publishing: The Freeth Report." Publishing Research Quarterly. 2008, pp. 165-174.

Hoynes, Michael. "Building a Brand for Independent Survival". Publishing Research Quarterly. 2001, pp. 15-20. .

Laing, A. Authors Using Social Media: Layers of Identity and the Online Author Community. Publishing Research Quarterly. 2017, pp. 254-267.

Lam, Wing, and Michael J. Harker. "Marketing and entrepreneurship: An integrated view from the entrepreneur's perspective." International Small Business Journal 33, no. 3 (2015): 321-348

Mark, Sullivan. “Are Books A Bad Bet? Why Small Publishers Think They're A

Winner.” Forbes, Forbes Magazine, 26 May 2017.

Microcosm Publishing. Accessed October 30 2017.

Milliot, Jim. “The Bad News About E-Books.” Publishers Weekly, 20 Jan. 2017.

Morrish, Sussie. "Entrepreneurial marketing: a strategy for the twenty-first centry?". Journal of Research in Marketing and Entrepreneurship. 2011, Vol.13(2), pp.110-119.

Nadeau, Jay. “Interview with Jay Nadeau- Biting Duck Press.” 5 Mar. 2018.

O’Connor, Justin. "The Cultural and Creative Industries: A Critical History," EKONOMIAZ. Revista vasca de Economía, Gobierno Vasco / Eusko Jaurlaritza / Basque Government. 2011. Vol. 78(03), pages 24-47.

"Ooligan Press." Ooligan Press, ooligan.pdx.edu/.

“Oregon Presses \& Magazines.” Literary Arts, literary-arts.org/what-we-do/oba-home/oregonwriters-and-publishers/

Perfect Day. Perfectday.com Accessed January 2018.

Propeller.Press. propellerbooks.com. Accessed January 2018. 
"Publishers." Consortium Book Sales \& Distribution, www.cbsd.com/publishers/.

Rowley, Jennifer and Jones, Rosalind. "Entrepreneurial marketing in small businesses: A conceptual exploration”. International Small Business Journal. 2011 Vol 29, Issue 1, pp. 25 - 36

Shaw, Eric. "A comment on the relationship between the history of marketing thought and the development of marketing theory" Marketing Theory. 2011. Vol 11, Issue 4, pp. 491 - 494

Thompson, John. Merchants of Culture: The Publishing Business in the $21^{\text {st }}$ Century. Print. 2012.

Tin House Books. Accessed October 30 2017.

Vaughn, Portia and Turner, Cherie. "Decoding via Coding: Analyzing Qualitative Text Data Through Thematic Coding and Survey Methodologies" Journal of Library Administration. 2015, pp 41-51.

\section{Appendixes}

Appendix A: Interview questions

(Questions taken from:

Fillis, Ian. "A biographical approach to researching entrepreneurship in the small firm". Management Decision. 2006, pp. 196-212.)

(1) Tell me about your business.

(2) What skills would you say you have?

(3) Have you always wanted to work in publishing?

(4) Do you make much effort to distinguish between your social and work life? (5) How would you say you responded to a new/challenging situation?

(6) Would you say you were creative? If you are, is this just an occasional thing or is it a continual, ongoing situation? Is this recent or have you always had this ability?

(7) Tell me about your ambitions.

(8) Do you think that not having the resources of the larger firm affects how you think/behave? What resources/skills would you say you lacked?

(9) Would you say you are: flexible in your approach; able to visualize/see problems easily; able to use your imagination; innovative; a risk taker; open to new ideas/new methods or do you prefer to always do things in the same way; curious; don't want to be controlled, but prefer to think for yourself; easily motivated; able to identify new opportunities; using networks/networking and building relationships to grow the business; not scared of making mistakes/failure. 
(10) How much time would you say you spent thinking compared to actually doing the job?

(11) Is lifestyle important to you?

(12) What are your strong points? Any weaknesses?

(13) Would you say you were entrepreneurial? Would you say you were any good at marketing?

(14) Do you like working with other people or prefer to do things on your own? Or does it depend on the situation?

(15) If you were going to employ other people, what would be the main requirements you would look for?

(16) Would you say you did things on the spur of the moment or do you spend time thinking and planning ahead?

(17) Do you think that being creative is an asset, some sort of competitive advantage?

(18) Would you say that your industry/business makes it easy to be creative or even necessary to be creative?

(19) How do you feel when you have completed a job?

(20) What's more important to you - things happening within the business or are you also concerned with what's happening around you?

(21) Would you describe yourself as an expert?

(22) What do you like most/least about your job?

(23) Do you think qualifications are important?

(24) How do you think - do you take time to reach a decision or is it sometimes more of a gut reaction?

(25) Do you like solving problems, being presented with a difficult task?

(26) Finally, any thoughts on the future direction of your business?

Appendix B: Consent form

\section{The Portland State University}

\section{Consent to Participate in Research}

Working Title:

The Biographical Approach to Marketing in Portland's Publishing Industry

\section{Introduction}

You are being asked to participate in a research study that is being done by Kate Jay, who is the Principal Investigator and Rachel Noorda, from the Department of English, at Portland State University in Portland, Oregon. This research is studying how, using the biographical approach, small publishers address marketing. The biographic approach seeks to understand a business in greater depth through an understanding of the owners and founders. This question is being analyzed because of its focus on the benefit of qualitative research for understanding marketing techniques. In that, this research seeks to discover how the business founders and owners own experience impacts how the company markets itself and its products.

You are being asked to participate in this study because, as a publisher, you know the industry in Portland better than anyone else from a personal perspective that this research is seeking to access.

This form will explain the research study, and will also explain the possible risks as well as the possible benefits to you. We encourage you to talk with your family and friends before you 
decide to take part in this research study. If you have any questions, please ask one of the study investigators.

What will happen if I decide to participate?

If you agree to participate, the following things will happen:

You will be interviewed in the location of your choosing for approximately an hour. It's suggested that this interview happens in a quiet place. You'll have access to the interview questions prior to the interview occurring and any questions for the researcher can be asked at any time.

How long will I be in this study?

Participation in this study will take a total of 1 hour over a period of a single instance.

What are the risks or side effects of being in this study?

There are minimal risks involved with the question of the study, including: risks of stress, emotional distress, inconvenience and possible loss of privacy and confidentiality.

For more information about risks and discomforts, feel free to ask Kate

What are the benefits to being in this study?

The benefit to the research being completed is growing the academic research of the publishing industry as a whole. Furthermore, the research seeks to showcase the importance of qualitative information and that information small business founders have is valuable.

How will my information be kept confidential?

We will take measures to protect the security of all your personal information, but we cannot guarantee confidentiality of all study data. Because the questions are personal in nature, asking about personal backgrounds and careers, the information will be identifiable. All interviews will be recorded in order to be transcribed, but both the interviews themselves and the transcripts will be kept in a locked office. Furthermore, all interviewees will have access to the final research prior to its publication so if information is present that an interviewee is uncomfortable with, it

Information contained in your study records is used by study staff. The Portland State University Institutional Review Board (IRB) that oversees human subject research and/or other entities may be permitted to access your records, and there may be times when we are required by law to share your information. It is the investigator's legal obligation to report child abuse, child neglect, elder abuse, harm to self or others or any life-threatening situation to the appropriate authorities, and; therefore, your confidentiality will not be maintained.

Your name will not be used in any published reports about this study.

Will I be paid for taking part in this study?

No.

Can I stop being in the study once I begin?

Your participation in this study is completely voluntary. You have the right to choose not to participate or to withdraw your participation at any point in this study without penalty or loss of benefits to which you are otherwise entitled. 
Whom can I call with questions about my rights as a research participant?

If you have questions regarding your rights as a research participant, you may call the PSU Office for Research Integrity at (503) 725-2227 or 1(877) 480-4400. The ORI is the office that supports the PSU Institutional Review Board (IRB). The IRB is a group of people from PSU and the community who provide independent oversight of safety and ethical issues related to research involving human participants. For more information, you may also access the IRB website at https://sites.google.com/a/pdx.edu/research/integrity. CONSENT

You are making a decision whether to participate in this study. Your signature below indicates that you have read the information provided (or the information was read to you). By signing this consent form, you are not waiving any of your legal rights as a research participant.

You have had an opportunity to ask questions and all questions have been answered to your satisfaction. By signing this consent form, you agree to participate in this study. A copy of this consent form will be provided to you.

$-$

Name of Adult Subject (print)
Signature of Adult Subject Date

\section{INVESTIGATOR SIGNATURE}

This research study has been explained to the participant and all of his/her questions have been answered. The participant understands the information described in this consent form and freely consents to participate.

$\overline{\text { Name of Investigator/ Research Team Member (type or print) }}$

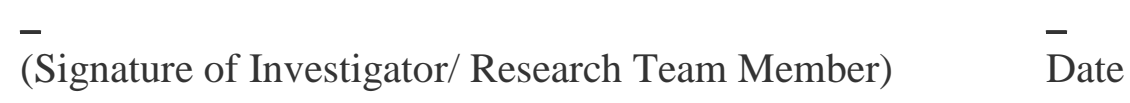

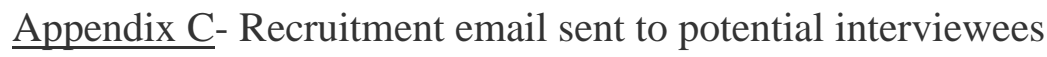

Hello,

My name is Kate Jay and I am an undergraduate student the Honors program at Portland State University. For my degree I am writing an undergraduate thesis based on my double majors in Marketing and English. These two fields lead me to researching publishing houses in Portland, which is why I'm reaching out to you.

My research involves interviewing the owners of local publishing houses (like yourself) in order to gain an understanding of how marketing knowledge is developed within the industry as well as how the personal history of individuals impacts their business.

I am reaching out to you is because I believe your knowledge will be immensely helpful for my research. I would like to set up an interview of approximately an hour in the location of your choosing. Feel free to respond to the email with any questions or concerns. 
I have attached a copy of the consent form which further explains my research as well as my interview questions. I also recognize that you are a busy person and may not have time to participate, which is of course completely understandable, I appreciate you reading my email nonetheless.

Again, any questions you have I will do my best to answer and thank you so much for your time, it is truly appreciated,

Appendix D: List of creative qualities, taken from: Fillis, Ian, and Andrew McAuley. "Modeling and measuring creativity at the interface." Journal of Marketing Theory and Practice 8, no. 2 (2000): 8-17.

\begin{tabular}{|c|c|c|}
\hline Openness to experience & $\begin{array}{l}\text { Observance-seeing things in } \\
\text { unusual ways }\end{array}$ & Curiosity \\
\hline $\begin{array}{l}\text { Accepting and reconciling } \\
\text { apparent opposites }\end{array}$ & Tolerance of ambiguity & $\begin{array}{l}\text { Independent in judgement, } \\
\text { thought, and action }\end{array}$ \\
\hline $\begin{array}{l}\text { Needing and assuming } \\
\text { autonomy }\end{array}$ & Self-reliance & $\begin{array}{l}\text { Not being subject to group } \\
\text { standards or control }\end{array}$ \\
\hline $\begin{array}{l}\text { Willingness to take calculated } \\
\text { risks }\end{array}$ & Persistence & Sensitivity to problems \\
\hline $\begin{array}{l}\text { Fluency-ability to generate } \\
\text { large numbers of ideas }\end{array}$ & Flexibility & Originality \\
\hline Responsiveness to feelings & $\begin{array}{l}\text { Openness to unconscious } \\
\text { phenomena }\end{array}$ & Motivation \\
\hline Freedom from fear of failure & Ability to concentrate & Thinking in images \\
\hline Selectivity & Opportunity-focused & Highly informal \\
\hline Limited planning & Limited resources & Simple structure \\
\hline Analytical skills & Knowledge & Experience \\
\hline Achievement motivation & Locus of control & Need for autonomy \\
\hline Determination & Self confidence and trust & Dedication \\
\hline Innovation & Goal seeking & Developing relationships \\
\hline Intuition & Judgement & Information gathering \\
\hline
\end{tabular}


Jay 43 